\title{
Lumpy skin disease (LSD) outbreak in Nepal
}

\author{
Sagar Regmi ${ }^{1}$ \\ ${ }^{1}$ Agriculture and Forestry University
}

September 11, 2020

\begin{abstract}
LSD is a notifiable disease caused by lumpy skin disease virus belonging to Poxviridae family leading to high economic losses. LSD is transmitted by an insect vector, contaminated vehicles, and equipment. It causes generalized lymphadenitis, circumscribed skin nodules, and subcutaneous edema of limbs and ventral parts of the body. The first case of LSD was seen in Nepal on 24th June 2020 in Morang. Jersey cross-bred showed higher susceptibility to LSD over Holstein-Friesian and buffalo. Morbidity and mortality were obtained to be around (3-7) \% and (0.5-1) \% in cattle and (2-3) \% and $0 \%$ in buffaloes respectively to date. The vaccine isn't available in Nepal and is being focused on the isolation and symptomatic treatment of infected animals.
\end{abstract}

\section{Introduction}

Lumpy skin disease (LSD) is a non-zoonotic re-emerging disease caused by a single strain of capripoxvirus from the family Poxviridae. Poxviridae is the family of the largest viruses which can cause disease in most domestic animals, except in dogs. Poxviridae possesses a large and complex genome consisting of a single, linear molecule of double-stranded DNA coding for around 200 proteins(Mulatu \& Feyisa, 2018). LSDV is stable for long periods at ambient temperature in dried scabs. LSDV can be destroyed at $55^{\circ} \mathrm{C}$ for 2 hours and $65^{\circ} \mathrm{C}$ for 30 minutes and can also be recovered from skin nodules kept at $-80^{\circ} \mathrm{C}$ for 10 years and infected tissue culture fluid stored at $4^{\circ} \mathrm{C}$ for 6 months(Tuppurainen et al., 2017). LSD virus demonstrates high susceptibility to the ether, chloroform, formalin, and some detergents, e.g. sodium dodecyl sulfate, phenol, sodium hypochlorite, Virkonß (2\%) and, quaternary ammonium compounds(Gerilovych \& Stegniy, 2016).

LSD is susceptible to cattle (Bos indicus and B. taurus) and water buffalo (Bubalus bubalis ) resulting in high economic losses as it leads to reduced milk production(Gari, Bonnet, Roger, \& Waret-Szkuta, 2011), infertility, abortion, and sometimes death(Davies, 1991). The serological surveys on wild ruminant species in Africa have not revealed a wildlife reservoir of LSDV and the virus appears to be highly host specific. But Young, Basson, \& Weiss, (1970) revealed that impala (Aepyceros melampus) and giraffe (Giraffa camelopardalis ) demonstrated the clinical signs of LSD after experimental inoculation with LSDV. A study in Ethiopia on differential breed susceptibility to LSD showed that Holstein Friesian or crossbred cattle exhibits higher morbidity and mortality compared to local zebu cattle(Brown C. \& Torres A., 2008).

\section{Mode of transmission}

LSD was recognized as a notifiable disease by the World Organization for Animal Health (OIE) as it causes significant economic losses((AHAW), 2015). The economic losses are the outcome of restrictions of animal products to the global trade and costly control and eradication measures. Insect vectors (mosquitoes, flies, ticks, etc.), contaminated needles, vehicles from the infected area play a major role in the transmission of this virus. LSD can spread rapidly during summer and autumn months when the environment is moist, warm favorable for the growth and reproduction of houseflies, mosquitoes, etc. Stomoxys, Biomyia fasciata, Tabanidae, Glossina, and Culicoides species are considered to be the main vector for transmission(Rueda, Patel, Axtell, \& Stinner, 1990). 


\section{Clinical signs}

LSD is characterized by biphasic fever $\left(40-41^{\circ} \mathrm{C}\right)$, the sudden appearance of firm circumscribed skin nodules that undergo necrosis, nodular lesions on intestinal mucosa on severe cases, subcutaneous edema of the limbs and ventral parts of the body, and a generalized lymphadenitis(Liu \& Venter, 2014) especially prescapular, precrural and subparotid(Barnard, Munz, Dumbell, \& Prozesky, 1994). The incubation period was about 4-12 days. It also results in excessive lachrymation and salivation containing Lumpy skin disease virus(LSDV)(Babiuk et al., 2008). Morbidity and mortality of LSD range between $10 \%$ and (1-3) \% respectively. The morbidity rate for LSD ranges from $5-45 \%$ depending on the abundance of insect vectors, breed of cattle affected, general health and nutritional status of the animals(FAO, 2014).

\section{Geographical distribution}

The disease was seen late in 1929 in Northern Rhodesia (Zambia) and was endemic to African countries for 50 years(Woods, 1988). LSD was found and diagnosed in East Africa (Kenya), Sudan and, West Africa in 1957, 1972, and 1974 respectively. Unconfirmed cases of LSD were reported in Oman and Kuwait between 1984 and 1988(House et al., 1990). It has been spreading rapidly since 2012 through the Middle East, south-east Europe, the Balkans, Caucasus and, Russia and into mainland Europe (Greece) in 2015. The reason behind the sporadic spread of LSD was unclear but multiple researchers presented various Hypotheses including climatic conditions favorable to LSDV spread, or civil conflicts(Beard, 2019). LSD appeared for the first time in Central Asia in July 2016 in Kazakhstan near the border with Russia and the outbreak was controlled with stamping out and a mass vaccination campaign(Europe, No, \& Gf-tads, 2018).

LSD was encountered on $12^{\text {th }}$ Aug 2019 in India and $3^{\text {rd }}$ Aug 2019 in China. Due to the presence of an open Indo-Nepal border, there was a higher risk of an outbreak of LSD in Nepal("Lumpy skin disease India:," 2019; Health, Centre, \& Affairs, 2020).

\section{Outbreak in Nepal}

The first outbreak of LSD was seen on $24^{\text {th }}$ June 2020 in Jersey cross-bred, Holstein-Friesian crossbred, and Local cattle of various age groups. The disease was reported to OIE on $29^{\text {th }}$ July 2020 . Based on recent data, 1,409 cases in cattle and 5 cases in buffaloes were recorded. Twelve deaths were reported in cattle. Similarly, 14,120 cattle and 172 buffaloes were found to be susceptible to LSD. Morbidity and mortality were recorded as (3-7) \% and (0.5-1) \% in cattle and (2-3) \% and $0 \%$ in buffaloes respectively to date. The disease is continuously spreading and Jersey breed of cattle was found to have higher susceptibility. LSD was seen in cattle and buffalo of (2-8) year's age group. The chart below shows that the no of new cases is decreasing.

Fig1: Line-graph showing the trend of the appearance of cases till date

Table1: Table containing data on all outbreak of LSD till date("Lumpy skin disease:Nepal," 2020)

Fig2: Map showing the location where LSD outbreak was recorded

Fig3: A Jersey cross-bred cow infected with LSD at Ratnanagar, Chitwan

Fig4: A Jersey calf with ruptured nodules on skin

Fig5: A Jersey cow with swollen pre-scapular lymph nodes

\section{Control and treatment}

The Source of the outbreak is not known yet and supportive treatments are given to the infected animals using antipyretics, antihistamines, and broad-spectrum antibiotics, fly repellent ointments. Quarantine, vector control, disinfection are the major control measures being applied. Vaccine for LSD is not available till date in Nepal.

\section{Conclusion}


LSD is one of the major trans-boundary disease affecting cattle and buffaloes and are spreading continuously. We must focus on the quarantine of imported animals, isolation of infected animals, and vaccination. Currently, the available vaccine does not provide each individual with solid protection resulting in the dissemination of the virus by insect vectors. However, the Neethling vaccine is highly effective to prevent morbidity of LSD and must be used for mass vaccination as soon as possible.

\section{Ethical statement}

This paper is under the ethical guidelines of Agriculture and Forestry University.

\section{Acknowledgment}

I would like to convey my deepest gratitude to my professors and colleagues for their continuous support and guidance.

\section{References}

(AHAW), E. P. on A. H. and W. (2015). Scientific Opinion on lumpy skin disease. EFSA Journal , 13 (1), 3986.

Babiuk, S., Bowden, T. R., Parkyn, G., Dalman, B., Manning, L., Neufeld, J., ... Boyle, D. B. (2008). Quantification of lumpy skin disease virus following experimental infection in cattle. Transboundary and Emerging Diseases , 55 (7), 299-307.

Barnard, B. J., Munz, E., Dumbell, K., \& Prozesky, L. (1994). Lumpy skin disease. Infectious Diseases of Livestock with Special Reference to Southern Africa , 1, 604-612.

Beard, P. M. (2019). Capripoxviruses, Parapoxviruses, and Other Poxviruses of Ruminants . Reference Module in Life Sciences . Elsevier Ltd. https://doi.org/10.1016/b978-0-12-809633-8.20934-5

Brown C. \& Torres A., E. (2008). (2008). Aetiology Epidemiology Diagnosis Prevention and Control References. The Veterinary Clinics of North America. Equine Practice, 1-4.

Davies, F. G. (1991). Lumpy skin disease. A capripox virus infection of cattle in Africa.

Europe, S., No, M., \& Gf-tads, T. (2018). Lumpy Skin Disease ( LSD ): a new challenge to the Veterinary Services of Central Asian countries,2016 (1), 1-2.

FAO. (2014). Emergence of lumpy skin disease in the Eastern Mediterranean Basin countries. Empres Watch , 30 (November).

Gari, G., Bonnet, P., Roger, F., \& Waret-Szkuta, A. (2011). Epidemiological aspects and financial impact of lumpy skin disease in Ethiopia. Preventive Veterinary Medicine , 102 (4), 274-283.

Gerilovych, A. P., \& Stegniy, B. T. (2016). LumPY SKIN DISEASE : CHARACTERIZATION AND POSSIBLE RISKS fOR CENTRAL AND EASTERN EuROPE,2 (3), 33-38.

House, J. A., Wilson, T. M., Nakashly, S. El, Karim, I. A., Ismail, I., Danaf, N. El, .. Ayoub, N. N. (1990). The isolation of lumpy skin disease virus and bovine herpesvirus-from cattle in Egypt. Journal of Veterinary Diagnostic Investigation, 2 (2), 111-115.

Liu, D., \& Venter, E. (2014). Lumpy Skin Disease Virus. Manual of Security Sensitive Microbes and Toxins , 665-678. https://doi.org/10.1201/b16752-64

Lumpy skin disease:Nepal. (2020) https://doi.org/10.2903/sp.efsa.2019.en-1751

Lumpy skin disease India: (2019). https://doi.org/10.2903/sp.efsa.2019.en-1751

$\begin{array}{llllll}\text { EFSA } & \text { Supporting } & \text { Publications } & , 16 & (11), & 1-2 . \\ \text { EFSA } & \text { Supporting } & \text { Publications } & , 16 & (11), & 1-2 .\end{array}$


Mulatu, E., \& Feyisa, A. (2018). Review: Lumpy Skin Disease.Journal of Veterinary Science 63 Technology , 09 (03). https://doi.org/10.4172/2157-7579.1000535

Rueda, L. M., Patel, K. J., Axtell, R. C., \& Stinner, R. E. (1990). Temperature-dependent development and survival rates of Culex quinquefasciatus and Aedes aegypti (Diptera: Culicidae). Journal of Medical Entomology, 27 (5), 892-898.

Tuppurainen, E. S. M., Venter, E. H., Shisler, J. L., Gari, G., Mekonnen, G. A., Juleff, N., .. Bowden, T. R. (2017). Capripoxvirus diseases: current status and opportunities for control.Transboundary and Emerging Diseases , 64 (3), 729-745.

Woods, J. A. (1988). Lumpy skin disease - a review. Tropical Animal Health and Production, 20 (1), 11-17.

Young, E., Basson, P. A., \& Weiss, K. E. (1970). Experimental infection of game animals with lumpy skin disease virus (prototype strain Neethling).

\section{Hosted file}

Fig.docx available at https://authorea.com/users/357049/articles/479806-lumpy-skin-diseaselsd-outbreak-in-nepal

\section{Hosted file}

table.docx available at https://authorea.com/users/357049/articles/479806-lumpy-skindisease-lsd-outbreak-in-nepal 